\title{
A Look into Rev. J. Todd's "Scene on the Ohio: The Solitary Grave" (1840): Critical Reading
}

Baker M. Bani-Khair*

Hashemite University, Zarqa, Jordan

Corresponding Author: Baker M. Bani-Khair, E-mail: bakribakr@yahoo.com

\section{ARTICLE INFO}

Article history

Received: December 04, 2017

Accepted: January 28, 2018

Published: April 30, 2018

Volume: 9 Issue: 2

Advance access: March 2018

Conflicts of interest: None

Funding: None

\begin{abstract}
Having researched and looked in some historical antebellum newspapers, I found an interesting story, which I think it represents a good example on antebellum literature that remained unknown since it once appeared in the newspaper two centuries ago. The story is entitled, "Scene on the Ohio: The Solitary Grave" by a writer named Rev. J. Todd. In fact, there are no resources that can tell us any information about the writer or the story. However, his story appeared in the Southern Recorder Newspaper, on Jan, 28, 1840, under The Milledgeville Historic Newspaper Archives, California Digital Newspaper Collections. In this essay, I focused on Todd's story in terms of style, structure, themes, and content, and I link it with the features of the Antebellum literature through explaining its distinguishing characteristics, references to culture, Ideology, and some other psychological aspects that match the common features of the Antebellum literature.
\end{abstract}

Key words:

Rev. Todd,

Antebellum,

Digital newspapers,

Solitary Grave,

Style

\section{INTRODUCTION}

In general, the short story in Antebellum Literature has significantly played an important role in maintaining the dominant features and patterns of cultural, social, philosophical, and ideological aspects of Antebellum age (Renaissance or New England Age). However, despite the significance of the short story and its tremendous contribution to antebellum literature which occupies an important space as a literary genre and as an actual representation of political and social conflicts during the Antebellum period, there are many literary works which did not arrive to us, or have never been given the attention they really deserve. Therefore, I think that historic newspapers from the Antebellum time period are still a rich source for literature that has not been documented during or after that time period, especially when considering the fact that the Renaissance age was a hard time, and many brilliant authors could not even afford to read, publish, or buy books. Being a convenient and public media source, the newspaper was one of the favorite ways of communicating with the public through which many writers had to write for people, so they can read on a daily basis. The newspaper was certainly a good way of communicating with the audience; and therefore, the public depended heavily on it for getting to know daily news, including daily written poems and short stories.
Having researched and looked in some historical Antebellum newspapers, I found an interesting story which I think it is one of the best examples on Antebellum literature that remained quite unknown since its first appearance in the newspaper two centuries ago. The story entiled "Scene on the Ohio: The Solitary Grave" which was written by Rev. J. Todd. In fact, there are no resources that can inform us about the writer or the story. However, his story appeared in the Southern Recorder Newspaper, on Jan, 28, 1840, under The Milledgeville Historic Newspaper Archives, California Digital Newspaper Collections. In this essay, I will focus on Todd's story in terms of style, structure, themes and content in an attempt to connect it with the features of the Antebellum literature through explaining its distinguishing characteristics, references to culture, spiritual values and morals that match the common and general features of the Antebellum literature.

\section{SUMMARY}

The narrator, an unnamed man, tells the story of a man whom he met when he was walking nearby the Ohio River. He gets tired, and then decides to rest under a hemlock tree which the narrator describes as giant and shadowy. As he was about to sleep, he was interrupted by a hunter named "Rodgers" 
who seems to be one of his old acquaintances that he has not seen since long time. As they were chatting and contemplating the river and the banks, Rodgers then gazed at the tree and the surrounding area where the narrator was sitting. He then started to look so melancholic and sad, and the tears were about to fall from his eyes. The narrator was shocked at the scene of his sadness and the tears in his eyes, and he wondered why he kept silent for a while. Then Rodgers tells him to look at the grave just near the hemlock tree. Rodgers then recounts his story that happened long time ago when he was young and strong. Rogers once accompanied a family as a pilot that planned to go to Kentucky on a steamboat. As Rodgers narrates his story, he explained that Captain Ward, the head of the family, planned to move his family from the east. On the boat, there were some people who managed the boat, in addition to his wife with her son and her widowed sister. The boat was crowded with a lot of stuff, pigs, cows, baggage, furniture, fowls and many others. As they were rowing for a long time down the river, they felt that it was the time for rest. Since they felt that they are now safe from the reach of the Indians from both sides of the river, they decide to rest nearby a giant hemlock tree. They then made a supper, and milked the cow and fed the children, and then decided to camp nearby the river. As they were about to sleep, they were attacked by the Indians who opened the fire upon them, then they ran to the boat, but found out that most of the animals they had were dead or dying, and that the son was severely injured as he was shot in the chest. Rogers then tells the influential and sentimental moments between the dying son, John, and his mother whose heart was broken at the scene of her only son dying in such a brutal way. The mother continued to encourage her son, so her son did not feel the pain, she asked him, " if he knew he was dying or not", Then he answered her, "yes, mother but are you hurt?", Rogers then continues to tell how the mother was just patient and so religious as she didn't lose her faith. The mother continued to say, "Jesus Christ, said the mother, for he was gone. She bent over him a few moments as if in silent prayer, then kissed his lips, and for the first time tears filled her eyes. Till that moment you would have thought she had been talking to a child just going to sleep-her voice was so calm and so mild." Rogers then continues to tell the boy's death scene and the mother's response as being religious and pious until they had buried him nearby that tree.

\section{ANALYSIS}

The story is told by Rodger, the second narrator, as a flashback or reminiscence. The story introduces a lot of suggestive themes and ideas in terms of its religious, psychological, social and cultural aspects of the Antebellum life, in addition to implying some traditional patterns about the Indians--Native Americans. For example, the writer refers to many implications that portray the Indian culture and the nature of the territorial conflict between the Whites and the Indians. According to Janette K. Murray, the literary text provides essential ideas and notions about the tribes and people implied in the language and text itself, she states that, "For the general reader, however, the major interest is in the tale itself after it has been translated into English. Even in translation the same tale from different tribes will not be identical. These differences are quite significant because they indicate the importance of particular beliefs as well as stylistic preferences." (154) Obviously, the story reflects those cultural and ideological patterns that represent the white and the Indian community which seem as only memories of the past from the narrator's perspective.

Despite the fact that the story is short with a simple plot, few characters, and limited settings, it is, in fact, like many other Antebellum stories and novels so rich in its didactic and moral elements. It is rich in terms of its lively images that portray the tension of the struggle and conflict. The story's portrait of life and death images is distinctive in the sense that they create catharsis toward the end of the story. The dynamics and the techniques that Todd uses in the story such as, juxtapositions, images of death and life, contrasts, and contradictions make the story an interesting and enjoyable to read. The powerful images he uses to inject life to the story are harmonized with the natural scenes and images of water, the flow of the river, the variety of animals on the boat, and the motion and sound effects of rowing and paddling. One of the things that mirrors the antebellum features is that the place is seen as residue and reminiscence of an actual post-war scene. The story's themes and implications are not different from the spirit of the antebellum age in general, especially regarding the theme of war and civil war as represented in the summary above. According to David S. Reynolds in Beneath The American Renaissance: the Subversive Imagination in the Age of Emerson and Melville, the period of the American Renaissance was the most copious literary period in the history of the U.S literature, he clarifies that, " the pre-Civil war period, identified by F. O. Mathiessen as the "American Renaissance," has long been recognized as the richest in America's literary history, the period that produced Emerson, Thoreau, Hawthorne, Melville, Poe, Whitman, Dickinson." (3) What also adds more vividness and strength to the classic literary texts was the ability of the Renaissance writers to bring about authentic and original materials, Reynolds continues to say, " Those writers now recognized as "major" had, of course, a profound debt to classic literature; but the key factor to understand is that, unlike some of their contemporaries, they transformed classic themes and devices into truly American texts by fusing them with native literary materials." (5)

Todd makes the story looks like a post war scene covered and encapsulated with gloom, death, sadness, melancholy, and remorse. Todd's story is similar to those diaries that recount war incidents and psychological traumas. The theme of struggle and conflict resulting from racism is obvious as it concerns two categories; the white and the Indian. As Lawrence Buell refers to the idea of provincial ideology, especially to some New England-Renaissance writers such as Emerson, he explains that the provincial conflict is not only related to place but also to race as a primary cultural but conflictual issue in the Renaissance age, he clarifies that, "The tribal consciousness underlying these remarks, particularly Emerson's, suggests the provincial ideology is not just 
a matter of place but of Race as well. Indeed regionalism and ethnicity are homologous and sometimes coextensive formations." (413) The struggle revolves around the land territories which symbolizes the dilemma of identity. It is noticeable from the settings and atmosphere of the story that the representation of the Indian culture comes to emphasize the conflictual and contrasting nature of reality which embodies both parties as sinful warriors. There are two important conflicts here; the internal conflict and external one. As we see in the story, the conflict between the Native Americans and the Settlers is paralleled with the conflict between the present and the past, the egotistic self and spirituality. The internal conflict is also shown as feelings of remorse and regret. While Rogers recounts his story about the religious woman, he still refers to himself as, "an old sinner who has a hard heart," but he also refers to the new generations who will better understand the story by using foreshadowing and implying the idea that the gap will be tiny between generations in the future. Rodgers ends his narrative by saying, "Perhaps my children might understand it better."

In fact, this open ending of the story gives hope as it foreshadows more peace and love in the future. I think the narrator means that future generations will get the moral and lesson out of this story and they will have the power to bridge gaps between nations and peoples regardless of color, origin, religion, and race. As Murray concludes her article by giving advice to the modern reader saying, "The literature of the Native American writer has grown and matured considerably in the past fifty years. It is not an easy struggle. Not only must the writer overcome the persistent stereotypes of the "noble savage" of the previous century, he must also go beyond the "social misfit" and "cultural conflicts" of the present. He must achieve a mastery of non-Indian techniques and literary forms and, at the same time, maintain his Native voice and vision." (164) Murray's advice here is to use critical thinking when we read and criticize literature, so we can include our own vision and reject any kind of exaggerations and stereotypes that can falsely distort or diminish cultural understanding.

\section{STYLE}

From a psychological point of view, I think that Todd's story is a similar echo for the many novels and short stories we read in the American Renaissance literature. Todd's story is both a moral and social story in terms of its richness in themes and ideas. Clearly, the story stands as a clever representation of faith contrasted with remorse, self-epiphany and cultural understanding. Despite the fact the story is narrated from a white man point of view, it still embodies and portrays native Indian culture as it contains and features Indian traditions. According to Murray, "To some people, Native American Literature means works written by non-Indians who have used Indian stories or Indian characters. There were some earlier writers, such as Helen Hunt Jackson, who knew Indians and presented them with authenticity." (158) Therefore, Indian traditions and conventions can similarly be represented in non-native American literature as it carries those characteristics and qualities which reflect the culture and the people alike.

In terms of style, the story is in a form of narrative that tells a story from the past using the past tense. However, the writer uses present tense when he talks about faith and religion. This is interesting because it shows us the consistent effect that faith and spirituality have on the plot and the characters and readers as well. Todd also uses a descriptive style of writing when he describes people, things, places, trees, boats, and characters. However, there seems to be some problems with using correct grammatical English which appeared few times in the story.

\section{CONCLUSION}

Todd's story reflects the cultural and social anxieties and concerns of the age itself. It mainly seems to criticize war. It is noticeable that the narrator keeps criticizing war and war consequences, as we see in this quotation when the narrator starts talking about war, Rodgers says, "the Whites and the Indians too, were continually making war upon each other. I don't know who was the most to blame. The whites killed the most, and the Indians were most cruel." Beside its criticism and didacticism, the story is simple to read and understand. However, I think that the story has many underlying and implicit themes, especially because we know very little about the author. I think it will be interesting to look at similar short stories written during that period of time by the same author if we found some others. This will definitely need to research some other historic newspapers to find out other similar important literary works.

\section{REFERENCES}

Todd, R. (1840). "Scene on the Ohio: The Solitary Grave." Southern Recorder Newspaper[Milledgeville] 28 Jan. 1840. Historic Newspaper Archives California Digital Newspaper Collections.

Murray, J. (1985)."What is Native American Literature?". The Canadian Journal of Native Studies, 2, 151-166.

Reynolds, D. S. (1988). Beneath the American Renaissance: The Subversive Imagination in the Age of Emerson and Melville. New York: Knopf, Print.

Buell, L. (1985). "The New England renaissance and American literary ethnocentrism". Prospects, 10, 409-422. 